Manfred SAGER ${ }^{1}$

\title{
THE HONEY AS A BIOINDICATOR OF THE ENVIRONMENT
}

\author{
MIÓD JAKO BIOINDYKATOR ZANIECZYSZCZENIA ŚRODOWISKA
}

\begin{abstract}
Monofloral rape, sunflower, linden and acacia honeys as well as honeys sampled within and around the Austrian towns Vienna and Linz, as well as in rural areas in Lower Austria, were analysed for main and trace elements. The results were tested to be used as indication of urban dust exposure. Main elements of the ash are K, $\mathrm{P}$, and $\mathrm{B}$, which are specific for plant origin. Ash based data correct for dilutions by the sugar matrix. They showed enrichments of $\mathrm{Cu}, \mathrm{Zn}$ and $\mathrm{Mo}$, whereas the contaminant elements $\mathrm{Cd}, \mathrm{Pb}$ and $\mathrm{Co}$ were found at about the same levels as expectable in dust. Ash-based Al, Fe, $\mathrm{Cr}$ and $\mathrm{Li}$ were much lower than soil levels obtainable from aqua regia. Among the monofloral honey samples, the effect of adjacent soil was largest for Mn. Most differences between rural areas and urban areas in Vienna and Linz were within experimental errors, both per sample weight and per ash weight. In cases honey samples are considered to trace contaminations, the additional use of ash-based data is recommended.
\end{abstract}

Keywords: honey, bioindicator, trace elements, boron, ash-based data, environmental contamination

\section{Introduction}

\section{Honey as a biomonitor}

Modern life style in connection with an enormous increase in the use of vehicles, the massive increase in power generation and the industrialization of agriculture have increased dramatically the pollution of the environment. Biological monitoring has the advantage of measuring integrated exposure from all sources.

Within a bee hive, about 10,000 individuals are continuously working daily upon about 1,000 blossoms, growing at an area of usually more than $7 \mathrm{~km}^{2}$ [1]. Contrary to the data from a single individual honeybee, effects of short-time variations in location and time get balanced by the bees' metabolism. Spatial differences will be masked by inherent differences in the elemental content of honey at any one location. Therefore it has been obvious to use honey as a bioindicator-substrate to estimate environmental pollution.

Modern multi-element determination methods enable to determine several elements of satisfactory recovery during the digestion procedure. Data from as many elements as

\footnotetext{
${ }^{1}$ Austrian Agency for Health and Food Safety, Spargelfeldstrasse 191, A-1220 Wien, Austria, phone 0043180288 42, email: herz18@tele2.at
} 
possible permit the discrimination between randomly occurring elements and those, which are indicative for effects whatsoever.

\section{Composition of honey in general}

Honey consists essentially of different sugars, predominantly fructose and glucose as well as other substances such as organic acids, enzymes and solid particles derived from honey collection. The colour of honey varies from nearly colourless to dark brown. The consistency can be fluid, viscous or partly to entirely crystallised. Flavour and aroma vary, and are due to the plant origin. Honey is a characteristically quite acidic item, its $\mathrm{pH}$ being between 3.2 and 4.5, which is low enough to be inhibitory to many animal pathogens. Gluconic acid was found to be the principal acid in honey. The acid-producing enzyme in honey is a glucose oxidase producing gluconic acid and hydrogen peroxide from glucose.

When the composition of various food items are compared, honey contains all elements at lowest levels, except C (from its sugar matrix), K and B [2].

\section{Plant sources}

When honey bees (Apis mellifera L.) feed mainly on nectar and pollen, they produce various kinds of floral honey, which can be characterized by flavours and pollen detected therein. But in forests, beneath various blossoms, honeybees collect also honeydew produced by aphids sucking the sap from the leaves of the trees. The inorganic matrix, which is termed as the ash, is received after combustion or volatilization of the sample. It can be calculated as the sum of the respective metal and non-metal oxides. Calculated ash and electrical conductivity are strongly correlated with the K-contents, which makes the main inorganic cation. Whereas $\mathrm{K}$ and most of the trace elements and thus the ash contents, reach higher levels in honeydew honeys, boron and $\mathrm{Ca}$ behave opposite (see e.g. Table 1) $[2,3]$.

Table 1

Calculated ash content and electrical conductivity in honey samples from East of Austria (A) and Greece (GR) and correlation between ash and conductivity (from [3])

\begin{tabular}{|c|c|c|c|c|c|}
\hline Honey & \multicolumn{2}{|c|}{ Ash [mg/kg] } & \multicolumn{2}{c|}{ Electr. conductivity [ $\boldsymbol{\mu S} / \mathbf{c m}]$} & Corr. \\
\hline & Median & Mean \pm SD $^{*}$ & Median & Mean \pm SD & \\
\hline Floral (A) & 1715 & $1653 \pm 423$ & 478 & $489 \pm 118$ & 0.8773 \\
\hline Honeydew (A) & 4521 & $4752 \pm 928$ & 1226 & $1461 \pm 498$ & 0.7315 \\
\hline & & & & & \\
\hline Floral (GR) & 770 & $1016 \pm 705$ & 261 & $303 \pm 176$ & 0.9646 \\
\hline Honeydew (GR) & 3091 & $3071 \pm 1363$ & 746 & $783 \pm 302$ & 0.9872 \\
\hline
\end{tabular}

* SD - Standard Deviation

\section{Environmental impacts on honey composition}

The composition of honey depends on green plant origin, the bee race, soil composition, distance to the sea, inputs from beekeeping and honey processing, as well as environmental contaminations by dust pollution covering the entire area (industries, cities; but not streets and railways) [2-5]. Many papers do not give any indication of these parameters, however.

The choice of the nutritional substrate is determined by availability and genetics of the bee race. Beneath plant selection, input of dust from the bees' hair and the metabolism in the honey-vesicle have to be considered. Less collection efficiency might lead to less 
dilution of adhering dust by sugars. In Europe, bee-keeping is restricted to apis mellifera only and all data from this work and from references cited, refer to honey from these [5].

As a highly viscous liquid, honey is a good adhesive for dust particles. Dust particles might emanate from the abrasion of rocks, buildings and roads, from combustion processes, from sea-salt aerosol and from organic debris [3]. The local influences of highways and roads seems marginal due to the sampling strategy of the bees [1] (see also below).

In order to exclude variations due to plant composition and environmental impacts, effects of soil composition get only revealed, when monofloral honeys from different obviously non-contaminated locations are compared. Rape was selected because it is easy to find fields of it at different sites. Among monofloral rape honey samples, manganese $(r=1.00)$, but also nickel, iron and molybdenum correlated with the respective aqua regia soluble contents in the soil, the most significant slope was observed for manganese. As manganese can be measured rather easily, it could be considered as indicative for the site of the origin of honey. The levels of most other elements were presumably subject to the metabolism and transport pathways of the rape plant, including the non-metabolically driven contents of lithium and strontium [4].

\section{Composition of commercially available honeys and historic samples}

Usually, data from about 1850 are taken as the zero for industrial contamination and metal inputs to the environment have grown after this time. For honey, however, this is not the case. Frequently, data about concentrations met in honey found in older papers are much higher than from recent ones, due to laboratory blanks and determinations close to the detection limits. It can be assumed, however, that in former times there was some input of dirt from centrifugation and further processing of the honey samples, as well as dust from unpaved roads and coal burning, which could be the case particularly for $3^{\text {rd }}$ World countries still today.

Within a government report [6] (detailed data have not been published yet), much lower levels of any ion in 122 commercial honey samples from Europe in 2009 (but samples from China, Tunisia and Australia were within this range) were found, than in 28 historic samples from 1927, found in the Tyrol and analysed by the same analytical methods, however [7]. Medians and ranges are given in Table 2.

Table 2

Median and ranges of commercially available honeys (2009) and historic samples

\begin{tabular}{|c|c|c|}
\hline Elements in honeys & Honeys (2009) & Honeys (1927) \\
\hline$[\mathbf{m g} / \mathbf{k g}]$ & $\mathbf{( 1 2 2}$ samples) [6] & (28 samples) [7] \\
\hline $\mathbf{K}$ & $746 / / 178-2930$ & $1709 / / 396-3966$ \\
\hline $\mathbf{N a}$ & $11.3 / / 4.1-43$ & $109 / / 61-559$ \\
\hline $\mathbf{F e}$ & $0.60 / / 0.14-3.07$ & $2.47 / / 0.99-17.5$ \\
\hline $\mathbf{Z n}$ & $0.57 / / 0.19-2.80$ & $13.0 / / 2.0-49.7$ \\
\hline $\mathbf{M n}$ & $0.66 / / 0.09-6.11$ & $1.44 / / 0.22-4.43$ \\
\hline $\mathbf{C u}$ & $0.144 / / 0.037-0.833$ & $0.34 / / 0.04-1.34$ \\
\hline $\mathbf{N i}$ & $0.030 / /<0.006-0.296$ & $0.150 / / 0.002-0.77$ \\
\hline $\mathbf{P b}$ & $0.011 / / 0.003-0.040$ & $0.148 / / 0.048-0.42$ \\
\hline $\mathbf{C r}$ & $0.0060 / / 0.0018-0.0351$ & $0.0096 / /<0.0003-0.0326$ \\
\hline $\mathbf{C o}$ & $0.0045 / / 0.0002-0.0465$ & $0.015 / / 0.0055-0.056$ \\
\hline $\mathbf{M o}$ & $0.0020 / / 0.0001-0.0092$ & $0.0067 / / 0.0009-0.0114$ \\
\hline $\mathbf{C d}$ & $0.0011 / / 0.0002-0.011$ & $0.0041 / / 0.0011-0.0116$ \\
\hline
\end{tabular}




\section{References about honey as an environmental indicator}

In the North of England, emissions of smelters around Liverpool and Birmingham markedly increased $\mathrm{Ag}, \mathrm{Cd}$ and $\mathrm{Pb}$ in honeys sampled within the entire area, whereas proximity to roads had no effect, in spite of intense use of alkylated $\mathrm{Pb}$-compounds in the fuel at this time. Similarly, no significant correlations between the concentrations met in honey and soils adjacent to the bee hives, were found [8].

In Poland, effects of a copper smelter were clearly visible in $\mathrm{As}, \mathrm{Cd}, \mathrm{Zn}$ and $\mathrm{Pb}$ honey contents, whereas seasonal effects were marginal (except for Zn) [9]. But trace elements in honeys from rural areas of Poland were close to samples from Sweden and Finland [10].

In the city of Rome, honeybees and, to a lesser extent, some of their products (pollen, propolis, wax), but not honey, were considered as representative bioindicators of environmental pollution for $\mathrm{Cd}, \mathrm{Cr}$ and $\mathrm{Pb}[11]$.

Other authors have investigated honey samples from Spain [12], Portugal [13], Chile [14], Egypt [15], or Turkey [16].

\section{Material and methods}

Most of the honey samples were obtained directly from beekeepers. Samples obtained at the roof of the biocenter university building Vienna, at the University of Natural Resources and Life Sciences Vienna, as well as the monofloral honeys were obtained from the working group of bee-research, established at the University of Natural Resources and Life Sciences Vienna.

The monofloral honeys were isolated directly from the honeycombs, which were cut with a plastic knife and the covers removed with a plastic comb. These samples were placed in plastic beakers and put into a drying oven $\left(40^{\circ} \mathrm{C}\right)$ in order to melt and to collect the outflowing honey from wax and pollen [4].

For the determination of total element contents, $4 \mathrm{~g}$ of honey samples were weighed into $50 \mathrm{~cm}^{3}$ Erlenmeyer flasks (precleaned with hydrochloric acid), $30 \mathrm{~cm}^{3}$ of suprapure nitric acid $(65 \%)$ were added and gently heated in a special fume cupboard equipped with alkaline washing of exhaust gases to absorb the nitrous oxides evolved and finally temperature was gradually increased. When the residue had come to almost dryness at $140^{\circ} \mathrm{C}, 25 \mathrm{~cm}^{3}$ of ultrapure water were added, mixed and filtered from wax into disposable plastic cups. Contrary to green plants containing cellulose, or feed and food samples containing substantial amounts of fat, addition of perchloric acid or hydrogen peroxide was not necessary. Each batch was accompanied by 2 blanks [2]. Water purified by reverse osmosis had to be used exclusively. Checks revealed that the wax contained even less minerals than the honey.

A simultaneously operating optical ICP (Perkin Elmer Optima 3000 XL) was used as a multi-element analytical tool, due to low analyte levels the sample solutions were used undiluted. $\mathrm{K}$ was determined by flame emission on a Perkin Elmer 3030 AAS after appropriate dilution (20-100 fold). $\mathrm{Pb}, \mathrm{Cd}, \mathrm{Cr}$ and $\mathrm{Mo}$ were analysed by graphite furnace AAS on a Perkin Elmer 3030 Z, equipped with Zeeman background correction.

The recovery of all elements investigated including boron was $>90 \%$, except for sulphur (recovery of S from methionine was just 40-64\%). Sulphur data given below are thus just minimum values; no sulphur data were found in the references, however. Barium traces seem to interact with the glass and respective data were not reliable. 
Detection limits were calculated from the standard deviations of the average of differences of the two blanks analysed within each batch. Considering $4 \mathrm{~g}$ sample digested and made up to $25 \mathrm{~cm}^{3}$, in the graphite furnace detection limits of $0.0001 \mathrm{mg} / \mathrm{kg}$ for Cd, $0.004 \mathrm{mg} / \mathrm{kg}$ for $\mathrm{Pb}, 0.001 \mathrm{mg} / \mathrm{kg}$ for $\underline{\mathrm{Mo}}$ and $0.0015 \mathrm{mg} / \mathrm{kg}$ for $\mathrm{Cr}$ had been achieved, which permits reliable data in most cases, whereas many data for $\mathrm{Co}$ and $\mathrm{V}$ were smaller than the detection limits achieved at the ICP-OES $(0.006 \mathrm{mg} / \mathrm{kg}$ for Co and $0.007 \mathrm{mg} / \mathrm{kg}$ for $\mathrm{V}$, resp.). In case an appreciable part of data is below detection limits, in the subsequent data tables, data ranges are given instead of mean and standard deviation.

\section{Results and discussion}

The composition of honey depends on the plant origin (floral honey - honeydew honey), soil composition, bee race, and possible contaminations from dust immissions and honey processing [2]. Within Europe, no other bees except apis mellifera have been admitted. Processing in the lab was done as clean as possible (see above). In spite of different climatic conditions and plant cover ([3], Table 2), similar concentration levels and differences between floral honey and honeydew honey appeared between samples from Austria and Greece. Correlations with soil composition obtained by aqua regia, however, are less than expected [4]. With respect to more recent data from Turkey [16], the data presented in this work tend to be at the same level in $\mathrm{Cu}, \mathrm{Mn}, \mathrm{Cr}$ and $\mathrm{Pb}$, somewhat lower in $\mathrm{Cd}, \mathrm{Zn}$ and $\mathrm{Fe}$, but slightly higher in $\mathrm{Al}$ and $\mathrm{Ni}$.

Monofloral honeys and soil composition (aqua regia) per sample weight (after [4])

\begin{tabular}{|c|c|c|c|c|c|c|}
\hline Element & Wieselburg & & Wr. Neustadt & & Hollabrunn & \\
\hline [mg/kg] & rape & soil & rape & soil & rape & soil \\
\hline & $N=23$ & & $N=25$ & & $N=19$ & \\
\hline Al & $0.458 \pm 0.191$ & 17887 & $0.486 \pm 0.115$ & 23225 & $0.297 \pm 0.089$ & 20859 \\
\hline B & $11.71 \pm 1.82$ & & $7.78 \pm 1.51$ & & $8.07 \pm 1.07$ & \\
\hline $\mathbf{C a}$ & $50.01 \pm 4.50$ & 7732 & $38.45 \pm 6.38$ & 72774 & $47.15 \pm 5.46$ & 76466 \\
\hline Cd & $0.00026 \pm 0.00015$ & 0.25 & $\begin{array}{c}0.00019 \\
\pm 0.00014\end{array}$ & 0.43 & $0.00027 \pm 0.00011$ & 0.18 \\
\hline Co & $<0.006-0.014$ & 11.38 & $<0.006-0.015$ & 10.26 & $0.018 \pm 0.009$ & 9.46 \\
\hline $\mathrm{Cr}$ & $0.00316 \pm 0.0023$ & 31.6 & $0.0056 \pm 0.0051$ & 29.3 & $0.0021 \pm 0.0019$ & 28.6 \\
\hline $\mathbf{C u}$ & $0.096 \pm 0.035$ & 11.8 & $0.266 \pm 0.066$ & 30.6 & $0.096 \pm 0.024$ & 13.4 \\
\hline $\mathbf{F e}$ & $0.65 \pm 0.17$ & 23340 & $0.34 \pm 0.08$ & 25806 & $0.53 \pm 0.09$ & 23953 \\
\hline $\mathbf{K}$ & $322 \pm 69$ & 3080 & $492 \pm 168$ & 6000 & $218 \pm 41$ & 3219 \\
\hline $\mathbf{L i}$ & $0.0013 \pm 0.0014$ & 17.9 & $0.0016 \pm 0.0007$ & 31.0 & $0.0006 \pm 0.0007$ & 24.6 \\
\hline Mg & $17.30 \pm 2.47$ & 4797 & $12.41 \pm 2.33$ & 20866 & $12.40 \pm 1.20$ & 12926 \\
\hline Mn & $0.549 \pm 0.134$ & 1400 & $0.252 \pm 0.078$ & 691 & $0.132 \pm 0.022$ & 435 \\
\hline Mo & $0.0041 \pm 0.0013$ & 0.705 & $0.0040 \pm 0.0014$ & 0.582 & $0.0040 \pm 0.0019$ & 0.417 \\
\hline $\mathrm{Na}$ & $6.66 \pm 1.23$ & 112.4 & $4.59 \pm 1.43$ & 191.7 & $3.08 \pm 0.69$ & 150.7 \\
\hline $\mathrm{Ni}$ & $0.057 \pm 0.019$ & 19.4 & $0.064 \pm 0.020$ & 19.9 & $0.104 \pm 0.043$ & 21.1 \\
\hline $\mathbf{P}$ & $37.9 \pm 7.7$ & 929 & $31.4 \pm 5.2$ & 1198 & $38.9 \pm 6.1$ & 586 \\
\hline $\mathbf{P b}$ & $0.0056 \pm 0.0035$ & 18.2 & $0.0057 \pm 0.0032$ & 56.7 & $<0.004$ & 13.0 \\
\hline $\mathbf{S}$ & $13.01 \pm 2.46$ & & $11.06 \pm 2.00$ & & $10.60 \pm 1.26$ & \\
\hline $\mathbf{S r}$ & $0.032 \pm 0.009$ & 19.8 & $0.030 \pm 0.010$ & 64.6 & $0.031 \pm 0.008$ & 91.9 \\
\hline $\mathbf{V}$ & $<0.007-0.025$ & 36.8 & $<0.007$ & 34.6 & - & 33.3 \\
\hline $\mathbf{Z n}$ & $0.355 \pm 0.132$ & 87.3 & $0.341 \pm 0.089$ & 118.0 & $0.879 \pm 0.258$ & 81.1 \\
\hline
\end{tabular}




\begin{tabular}{|c|c|c|c|c|c|c|}
\hline Element & Hollabrunn & & Hollabrunn & & Hirschstetten & \\
\hline [mg/kg] & sunflower & soil & acacia & soil & linden & soil \\
\hline & $N=25$ & & $N=\mathbf{2 4}$ & & $N=\mathbf{2 0}$ & \\
\hline Al & $0.171 \pm 0.101$ & 25071 & $0.083 \pm 0.050$ & 11961 & $0.467 \pm 0.129$ & 17926 \\
\hline $\mathbf{B}$ & $8.84 \pm 1.00$ & & $2.646 \pm 0.608$ & & $11.06 \pm 2.30$ & 5.8 \\
\hline $\mathbf{C a}$ & $74.49 \pm 7.52$ & 81007 & $6.86 \pm 2.94$ & 47125 & $62.68 \pm 7.08$ & 78537 \\
\hline Cd & $0.00035 \pm 0.00012$ & 0.15 & $0.00008 \pm 0.00004$ & 0.18 & $0.00048 \pm 0.00007$ & 0.127 \\
\hline Co & $<0.006-0.013$ & 10.14 & & 5.68 & $<0.006-0.014$ & 9.97 \\
\hline $\mathrm{Cr}$ & $0.0038 \pm 0.0019$ & 33.6 & $0.0054 \pm 0.0041$ & 17.8 & $0.0036 \pm 0.0014$ & 37.4 \\
\hline $\mathrm{Cu}$ & $0.222 \pm 0.031$ & 35.4 & $0.077 \pm 0.034$ & 10.4 & $0.264 \pm 0.049$ & 23.8 \\
\hline $\mathbf{F e}$ & $0.15 \pm 0.04$ & 24934 & $0.17 \pm 0.07$ & 14394 & $1.40 \pm 0.19$ & 17682 \\
\hline $\mathbf{K}$ & $353 \pm 56$ & 3944 & $174 \pm 8$ & 1456 & $678 \pm 25$ & \\
\hline $\mathbf{L i}$ & $0.0005 \pm 0.0003$ & 25.6 & $0.0004 \pm 0.0003$ & 10.7 & $0.0128 \pm 0.0021$ & 22.0 \\
\hline Mg & $16.45 \pm 2.12$ & 7517 & $2.43 \pm 0.56$ & 7683 & $22.93 \pm 4.81$ & 23324 \\
\hline Mn & $0.103 \pm 0.010$ & 484 & $0.023 \pm 0.003$ & 320 & $0.285 \pm 0.032$ & 486 \\
\hline Mo & $0.0039 \pm 0.0026$ & 0.364 & $0.0026 \pm 0.0016$ & 0.283 & $0.0038 \pm 0.0013$ & 0.02 \\
\hline $\mathbf{N a}$ & $2.30 \pm 1.45$ & 137.5 & $1.96 \pm 0.57$ & 71.4 & $17.99 \pm 7.51$ & 148 \\
\hline $\mathbf{N i}$ & $0.047 \pm 0.022$ & 25.8 & $0.040 \pm 0.016$ & 13.9 & $0.032 \pm 0.031$ & 31.5 \\
\hline $\mathbf{P}$ & $36.2 \pm 3.4$ & 606 & $21.6 \pm 1.5$ & 308 & $69.6 \pm 10.8$ & 887 \\
\hline $\mathbf{P b}$ & $0.0178 \pm 0.0106$ & 11.9 & $0.0049 \pm 0.0058$ & 13.8 & $0.0327 \pm 0.0102$ & 18.7 \\
\hline $\mathbf{S}^{*}$ & $7.96 \pm 0.95$ & & $2.84 \pm 0.56$ & & $20.37 \pm 4.45$ & 350 \\
\hline $\mathrm{Sr}$ & $0.025 \pm 0.004$ & 64.3 & $0.007 \pm 0.003$ & 34.2 & $0.111 \pm 0.012$ & 140 \\
\hline $\mathbf{V}$ & $<0.007$ & 38.9 & $<0.007$ & 19.3 & $<0.007$ & 34.2 \\
\hline Zn & $1.254 \pm 0.419$ & 72.3 & $0.647 \pm 0.310$ & 59.1 & $1.734 \pm 0.457$ & 71.0 \\
\hline
\end{tabular}

* incomplete recovery of methionine; $N$ - number of samples

If element contents is taken per sample weight, data presented in Tables 3, 5 and 7 show very low levels of inorganic matrix elements, except for $\mathrm{K}$ and $\mathrm{B}$. Indeed, levels met in honey are usually lowest among various food items, maybe except for sugar (not investigated). High boron is probably also a tool to detect forgeries of honey by coloured sugar solutions. Antibacterial activities of honey has been known for more than a century (first report in 1892, reviewed in [17]). Beneath osmotic effects because of low water activity, acidic $\mathrm{pH}$ and enzymes like glucose oxidase, high boron contents might be a reason of antibacterial activities also.

\section{Ash-based data}

Determinations of all main elements permit to calculate a presumable ash contents from the sum of the elements after transformation to the respective oxides (as it is usual in geology). Tables 4, 6 and 8 contain respective data referring to ash. These ash-based data correct for dilution by various sugars and else organics.

Beneath pollen composition for floral honeys, and transported loads in the phloem sap in case of honeydew honeys, some input via dust immission might occur. Dust immission measurements were not available on site, but it turned out that among the ash-based data, $\mathrm{Cd}, \mathrm{Pb}, \mathrm{Mn}$ and $\mathrm{Sr}$ were found to range within the levels met in arable soils, whereas $\mathrm{Cu}$, $\mathrm{Mo}, \mathrm{Ni}, \mathrm{Zn}$ and above all B were enriched, and on the other hand, $\mathrm{Al}, \mathrm{Fe}, \mathrm{Cr}, \mathrm{Li}$ and $\mathrm{V}$ were depleted (Tables $4,6,8$ ), presumably due to green plant physiology.

For some of the samples, pollen analyses and electrical conductivity of $10 \%$ sample solutions were available. Ash contents, calculated as the sum of the respective metal and non-metal oxides, as well as electrical conductivity, are clearly different for floral and honeydew samples. Because $\mathrm{K}$ is undoubtedly the main inorganic component of honey, 
some smaller labs may limit their investigations to determine $\mathrm{K}$ and electrical conductivity. A look at Tables 4, 6 and 8 shows that calculations of total ash from $\mathrm{K}$ only are not reliable, however.

Ash-based data might reflect soil influences even more (Table 4), particularly if the elements get sorted in the order of descending concentration per ash.

Table 4

Monofloral honeys and soil composition (aqua regia) per ash weight ( $\mathrm{B}$ and $\mathrm{S}$ in soils from $\mathrm{KClO}_{3}$-digests)

\begin{tabular}{|c|c|c|c|c|c|c|}
\hline Substance & Wieselburg & Soil & Wr. Neustadt & Soil & Hollabrunn & Soil \\
\hline \multirow[t]{2}{*}{ [\%] } & rape & & rape & & rape & \\
\hline & $N=\mathbf{2 3}$ & & $N=25$ & & $N=19$ & \\
\hline $\mathrm{K}_{2} \mathrm{O}$ & $58.85 \pm 4.39$ & 0.37 & $72.98 \pm 5.48$ & 0.72 & $52.54 \pm 4.61$ & 0.39 \\
\hline $\mathbf{P}_{2} \mathbf{O}_{5}$ & $13.18 \pm 2.31$ & 0.21 & $9.36 \pm 1.97$ & 0.27 & $17.94 \pm 1.92$ & 0.13 \\
\hline $\mathrm{CaO}$ & $10.75 \pm 1.50$ & 1.08 & $7.06 \pm 1.71$ & 10.19 & $13.49 \pm 2.51$ & 10.71 \\
\hline MgO & $4.38 \pm 0.40$ & 0.80 & $2.65 \pm 0.48$ & 3.46 & $4.18 \pm 0.57$ & 2.14 \\
\hline $\mathrm{SO}_{3}{ }^{*}$ & $4.92 \pm 0.68$ & - & $3.61 \pm 0.51$ & - & $5.37 \pm 0.69$ & \\
\hline $\mathrm{Na}_{2} \mathrm{O}$ & $1.39 \pm 0.30$ & 0.015 & $0.77 \pm 0.16$ & 0.026 & $0.85 \pm 0.17$ & 0.020 \\
\hline $\mathrm{B}_{2} \mathrm{O}_{3}$ & $5.74 \pm 1.51$ & - & $3.35 \pm 1.05$ & - & $5.37 \pm 0.88$ & \\
\hline \multicolumn{7}{|l|}{$[\mathrm{mg} / \mathrm{kg}]$} \\
\hline Al & $674 \pm 270$ & 17887 & $613 \pm 155$ & 23225 & $607 \pm 172$ & 20859 \\
\hline $\mathbf{C d}$ & $0.406 \pm 0.213$ & 0.25 & $0.264 \pm 0.222$ & 0.43 & $0.560 \pm 0.246$ & 0.18 \\
\hline Co & $<6-21$ & 11.38 & $8-20$ & 10.26 & $36.3 \pm 16.6$ & 9.46 \\
\hline $\mathrm{Cr}$ & $4.28 \pm 4.00$ & 31.6 & $7.86 \pm 6.78$ & 29.3 & $4.43 \pm 4.19$ & 28.6 \\
\hline $\mathbf{C u}$ & $150 \pm 51$ & 11.8 & $338 \pm 60$ & 30.6 & $196 \pm 45$ & 13.4 \\
\hline $\mathbf{F e}$ & $962 \pm 198$ & 23340 & $452 \pm 137$ & 25806 & $1082 \pm 183$ & 23953 \\
\hline $\mathbf{L i}$ & $1.9 \pm 1.9$ & 17.9 & $2.1 \pm 1.0$ & 31.0 & $1.2 \pm 1.2$ & 24.6 \\
\hline Mn & $834 \pm 75$ & 1400 & $318 \pm 81$ & 691 & $270 \pm 61$ & 435 \\
\hline Mo & $6.04 \pm 1.85$ & 0.705 & $5.49 \pm 2.07$ & 0.582 & $8.15 \pm 3.84$ & 0.417 \\
\hline $\mathrm{Ni}$ & $86 \pm 27$ & 19.4 & $80 \pm 39$ & 19.9 & $206 \pm 74$ & 21.1 \\
\hline $\mathbf{P b}$ & $9.1 \pm 5.1$ & 18.2 & $8.2 \pm 5.3$ & 56.7 & $<10$ & 13.0 \\
\hline $\mathbf{S r}$ & $47 \pm 12$ & 19.8 & $39 \pm 12$ & 64.6 & $64 \pm 20$ & 91.9 \\
\hline $\mathbf{V}$ & $<3-43$ & 36.8 & $<6$ & 34.6 & - & 33.3 \\
\hline $\mathbf{Z n}$ & $545 \pm 182$ & 87.3 & $442 \pm 75$ & 118.0 & $1799 \pm 537$ & 81.1 \\
\hline
\end{tabular}

\begin{tabular}{|c|c|c|c|c|c|c|}
\hline Substance & Hollabrunn & Soil & Hollabrunn & Soil & Hirschstetten & Soil \\
\hline \multirow[t]{2}{*}[\%]{} & sunflower & & acacia & & linden & \\
\hline & $N=25$ & & $N=\mathbf{2 4}$ & & $N=\mathbf{2 0}$ & \\
\hline $\mathrm{K}_{2} \mathrm{O}$ & $63.29 \pm 6.04$ & 0.48 & $71.91 \pm 1.64$ & 0.18 & $69.44 \pm 1.59$ & 1.90 \\
\hline $\mathbf{P}_{2} \mathbf{O}_{5}$ & $12.16 \pm 1.10$ & 0.14 & $17.05 \pm 1.35$ & 0.07 & $12.27 \pm 0.88$ & 0.17 \\
\hline $\mathrm{CaO}$ & $15.87 \pm 3.36$ & 11.34 & $3.40 \pm 1.48$ & 6.60 & $7.29 \pm 0.29$ & 11.54 \\
\hline MgO & $3.95 \pm 0.36$ & 1.252 & $1.36 \pm 0.30$ & 1.27 & $2.79 \pm 0.12$ & 4.43 \\
\hline $\mathrm{SO}_{3}{ }^{*}$ & $2.92 \pm 0.46$ & & $2.40 \pm 0.46$ & & $3.70 \pm 0.19$ & 0.088 \\
\hline $\mathrm{Na}_{2} \mathrm{O}$ & $0.47 \pm 0.32$ & 0.019 & $0.94 \pm 0.31$ & 0.010 & $1.51 \pm 0.23$ & 0.78 \\
\hline $\mathrm{B}_{2} \mathrm{O}_{3}$ & $4.18 \pm 0.59$ & & $2.89 \pm 0.67$ & & $2.71 \pm 0.14$ & 0.0015 \\
\hline \multicolumn{7}{|l|}{ [mg/kg] } \\
\hline Al & $272 \pm 203$ & 25071 & $288 \pm 175$ & 11961 & $381 \pm 97$ & 17926 \\
\hline Cd & $0.543 \pm 0.185$ & 0.15 & $0.274 \pm 0.126$ & 0.18 & $0.392 \pm 0.062$ & 0.127 \\
\hline Co & $<7-27$ & 10.14 & & 5.68 & $<5-12$ & 9.97 \\
\hline $\mathrm{Cr}$ & $5.75 \pm 2.95$ & 33.6 & $21.2 \pm 13.3$ & 17.8 & $2.95 \pm 1.20$ & 37.4 \\
\hline $\mathrm{Cu}$ & $330 \pm 68$ & 35.4 & $258 \pm 120$ & 10.4 & $216 \pm 32$ & 23.8 \\
\hline $\mathbf{F e}$ & $246 \pm 91$ & 24934 & $577 \pm 237$ & 14394 & $1144 \pm 124$ & 17682 \\
\hline $\mathbf{L i}$ & $0.8 \pm 0.4$ & 25.6 & $1.5 \pm 1.1$ & 10.7 & $10.5 \pm 1.7$ & 22.0 \\
\hline Mn & $149 \pm 13$ & 484 & $78 \pm 9$ & 320 & $234 \pm 19$ & 486 \\
\hline Mo & $5.70 \pm 4.00$ & 0.364 & $8.07 \pm 6.35$ & 0.283 & $3.17 \pm 1.20$ & 0.02 \\
\hline $\mathrm{Ni}$ & $66 \pm 31$ & 25.8 & $132 \pm 61$ & 13.9 & $27 \pm 26$ & 31.5 \\
\hline
\end{tabular}




\begin{tabular}{|c|c|c|c|c|c|c|}
\hline Substance & Hollabrunn & Soil & Hollabrunn & Soil & Hirschstetten & Soil \\
\hline$[\mathbf{m g} / \mathbf{k g}]$ & sunflower & & acacia & & linden & \\
\hline & $\mathbf{N = \mathbf { 2 5 }}$ & & $\boldsymbol{N = \mathbf { 2 4 }}$ & & $\boldsymbol{N}=\mathbf{2 0}$ & \\
\hline $\mathbf{P b}$ & $28.6 \pm 16.9$ & 11.9 & $26.4 \pm 19.6$ & 13.8 & $27.0 \pm 8.5$ & 18.7 \\
\hline $\mathbf{S r}$ & $38 \pm 9$ & 64.3 & $24 \pm 10$ & 34.2 & $91 \pm 8$ & 140 \\
\hline $\mathbf{V}$ & $<3$ & 38.9 & $<3$ & 19.3 & $<3$ & 34.2 \\
\hline $\mathbf{Z n}$ & $1853 \pm 727$ & 72.3 & $2081 \pm 1111$ & 59.1 & $1417 \pm 335$ & 71.0 \\
\hline
\end{tabular}

incomplete recovery of methionine; $N$ - number of samples

\section{Monofloral honeys}

Analysis of monofloral honeys from presumably non-contaminated sites (Table 3) shows that both the kind of plant and the soil composition influence honey composition. Monofloral honeys were collected in fields of rapeseeds and sunflowers and compared with aqua regia data from soils sampled at the site of the bee hive (Table 3; [4]). Monofloral honey of the similar plant origin differ at various sites, and vice versa. From this, estimations of the composition of non-contaminated honey from pollen analysis resp. plant origin will fail.

Monofloral honeys are not easily to obtain, and data are hardly found in the literature. The beekeeper has to move the hives to the field or the orchard just in time, collect the honey immediately after flowering and move the hives elsewhere. Because flowering lasts only a few weeks, bees have to get their nutrition from other sites during the rest of the season. Collection of monofloral honey was only possible to be done by colleagues from the beekeeping department in our house.

The selected sites were all situated in Lower Austria and differed in soil type and climate, but fertilization rate was about equal. At Hollabrunn, we meet a calcic chernozem on loess ( $\mathrm{pH}$ 7.4), at Holzing (near Wieselburg) a haplic gleysol (pH 6.8) and at Wiener Neustadt a gleyic phaeozem ( $\mathrm{pH} 7.5)$. Whereas the original data from rape honey and sunflower honey correlated with $\mathrm{Mn}, \mathrm{Ni}, \mathrm{Fe}$ and Mo aqua regia soluble contents of the soil, the ash-based data correlated with $\mathrm{Mn}$ and $\mathrm{Cu}$ [4].

With respect to floral and honeydew honeys sampled in gardens and close to woods, monofloral honeys from rape, sunflowers, acacia and lindens contain higher proportions of $\mathrm{P}$ and $\mathrm{Ca}$ over $\mathrm{K}$, which can be more clearly seen in the composition of (calculated) total ash contents in Tables 4, 6 and 8 .

\section{Differences between urban and rural areas}

Within Table 5, data from honeys sampled within a rural area partially covered with woods and no close industrial emission (Scheibbs district), are compared with honey data from western suburbs of Vienna and Vienna Woods, from gardens in the northern part of Vienna (around the University of Natural Ressources and Life Sciences Vienna), as well as from a university building close to a highway and railway station (Biocenter Althanstrasse). Differences in plant cover result in differences in $\mathrm{K}, \mathrm{Cu}$, and $\mathrm{Zn}$ contents. Elements indicating pollution, like $\mathrm{Cd}, \mathrm{Pb}, \mathrm{Cr}$, and $\mathrm{Ni}$, were found at about the same levels.

Similarly, corresponding calculated ash based data (Table 6) did not show enrichments of pollutant elements at the urban site. 
Honey samples from Lower Austria and Vienna, per sample weight

Table 5

\begin{tabular}{|c|c|c|c|c|}
\hline Element & $\begin{array}{l}\text { Scheibbs district } \\
\text { (Lower Austria) }\end{array}$ & $\begin{array}{l}\text { West of Vienna - } \\
\text { Vienna Woods }\end{array}$ & $\begin{array}{c}\text { Univ. of Nat. Res. Life } \\
\text { Sci. }\end{array}$ & Univ. Biocenter \\
\hline [mg/kg] & $N=16$ & $N=11$ & $N=7$ & $N=5$ \\
\hline Al & $1.86 \pm 1.10$ & $2.68 \pm 2.86$ & $0.99 \pm 0.61$ & $0.94 \pm 0.33$ \\
\hline As & & $0.0098 \pm 0.0033$ & & \\
\hline B & $5.29 \pm 1.51$ & $7.41 \pm 3.62$ & $4.51 \pm 1.45$ & $6.34 \pm 3.82$ \\
\hline $\mathrm{Ca}$ & $33.69 \pm 8.12$ & $40.8 \pm 13.8$ & $41.12 \pm 9.34$ & $33.35 \pm 6.50$ \\
\hline Cd & $0.0083 \pm 0.0060$ & $0.0038 \pm 0.0054$ & $0.0019 \pm 0.0017$ & $0.0008 \pm 0.0004$ \\
\hline Co & $<0.006-0.046$ & $<0.006-0.028$ & $<0.006-0.023$ & $<0.006$ \\
\hline $\mathrm{Cr}$ & $0.0047 \pm 0.0024$ & & $0.0065 \pm 0.0047$ & $0.0079 \pm 0.0049$ \\
\hline $\mathbf{C u}$ & $0.773 \pm 0.303$ & $0.340 \pm 0.339$ & $0.276 \pm 0.053$ & $0.211 \pm 0.123$ \\
\hline $\mathbf{F e}$ & $1.49 \pm 0.92$ & $1.59 \pm 1.18$ & $1.53 \pm 0.98$ & $0.84 \pm 0.52$ \\
\hline $\mathbf{K}$ & $2268 \pm 847$ & $1161 \pm 732$ & $1434 \pm 295$ & $921 \pm 309$ \\
\hline $\mathbf{L i}$ & $0.0087 \pm 0.0036$ & $0.0054 \pm 0.0030$ & $0.0098 \pm 0.0037$ & $0.0047 \pm 0.0017$ \\
\hline Mg & $65.5 \pm 47.8$ & $25.1 \pm 18.3$ & $18.35 \pm 2.59$ & $11.68 \pm 2.27$ \\
\hline Mn & $2.54 \pm 1.77$ & $1.32 \pm 1.28$ & $0.432 \pm 0.249$ & $0.189 \pm 0.037$ \\
\hline Mo & $0.0178 \pm 0.0144$ & $0.0106 \pm 0.0018$ & $0.0050 \pm 0.0061$ & $0.0098 \pm 0.0026$ \\
\hline$\overline{\mathrm{Na}}$ & $14.75 \pm 5.34$ & $6.99 \pm 2.58$ & $7.10 \pm 2.03$ & $5.47 \pm 1.72$ \\
\hline $\mathbf{N i}$ & $0.208 \pm 0.129$ & $0.218 \pm 0.193$ & $0.152 \pm 0.134$ & $0.072 \pm 0.017$ \\
\hline $\mathbf{P}$ & $78.8 \pm 27.2$ & $53.6 \pm 19.0$ & $52.1 \pm 10.9$ & $38.2 \pm 3.9$ \\
\hline $\mathbf{P b}$ & $0.019 \pm 0.010$ & $0.019 \pm 0.017$ & $0.049 \pm 0.050$ & $0.032 \pm 0.018$ \\
\hline $\mathbf{S}^{*}$ & $27.4 \pm 12.2$ & $15.51 \pm 8.64$ & $18.05 \pm 5.28$ & $14.30 \pm 3.30$ \\
\hline $\mathbf{S r}$ & $0.112 \pm 0.054$ & $0.092 \pm 0.049$ & $0.094 \pm 0.036$ & $0.059 \pm 0.014$ \\
\hline $\mathbf{V}$ & $<0.007$ & $<0.007$ & $<0.007-0.015$ & $<0.007$ \\
\hline $\mathbf{Z n}$ & $2.32 \pm 1.21$ & $1.06 \pm 0.99$ & $0.63 \pm 0.21$ & $0.91 \pm 0.78$ \\
\hline
\end{tabular}

${ }^{*}$ incomplete recovery of methionine; $N$ - number of samples

Table 6

Honey samples from Lower Austria and Vienna, main element composition and trace elements per ash weight

\begin{tabular}{|c|c|c|c|c|}
\hline Substance & $\begin{array}{l}\text { Scheibbs district } \\
\text { (Lower Austria) }\end{array}$ & $\begin{array}{l}\text { West of Vienna - } \\
\text { Vienna Woods }\end{array}$ & $\begin{array}{l}\text { Univ. of Nat. Res. Life } \\
\text { Sci. } \\
\end{array}$ & Univ. Biocenter \\
\hline$[\%]$ & $N=16$ & $N=11$ & $N=7$ & $N=5$ \\
\hline $\mathrm{K}_{2} \mathrm{O}$ & $85.51 \pm 1.81$ & $77.5 \pm 11.9$ & $85.78 \pm 2.16$ & $80.47 \pm 8.32$ \\
\hline $\mathbf{P}_{2} \mathbf{O}_{5}$ & $5.97 \pm 1.71$ & $8.56 \pm 3.29$ & $6.04 \pm 1.21$ & $7.02 \pm 2.48$ \\
\hline $\mathrm{CaO}$ & $1.77 \pm 0.95$ & $4.57 \pm 2.85$ & $2.91 \pm 0.69$ & $4.00 \pm 2.39$ \\
\hline MgO & $3.03 \pm 1.38$ & $2.46 \pm 0.75$ & $1.55 \pm 0.29$ & $1.58 \pm 0.75$ \\
\hline $\mathrm{SO}_{3}{ }^{*}$ & $2.12 \pm 0.39$ & $3.44 \pm 3.35$ & $2.24 \pm 0.45$ & $2.73 \pm 0.50$ \\
\hline $\mathrm{Na}_{2} \mathrm{O}$ & $0.76 \pm 0.47$ & $0.65 \pm 0.25$ & $0.49 \pm 0.18$ & $0.66 \pm 0.52$ \\
\hline $\mathrm{B}_{2} \mathrm{O}_{3}$ & $0.65 \pm 0.41$ & $2.33 \pm 2.33$ & $0.77 \pm 0.39$ & $0.620 \pm 0.705$ \\
\hline \multicolumn{5}{|l|}{$[\mathrm{mg} / \mathrm{kg}]$} \\
\hline Al & $556 \pm 230$ & $1457 \pm 987$ & $536 \pm 392$ & $827 \pm 491$ \\
\hline As & & $8.65 \pm 5.86$ & & \\
\hline Cd & $2.42 \pm 1.32$ & $1.63 \pm 1.71$ & $0.976 \pm 0.975$ & $0.609 \pm 0.244$ \\
\hline Co & $<2-29$ & $<3-16$ & $<3-13$ & $<3$ \\
\hline $\mathrm{Cr}$ & $1.57 \pm 0.89$ & & $3.12 \pm 2.22$ & $4.49 \pm 3.96$ \\
\hline $\mathbf{C u}$ & $243 \pm 43$ & $179 \pm 92$ & $142 \pm 40$ & $149 \pm 68$ \\
\hline $\mathbf{F e}$ & $431 \pm 131$ & $1078 \pm 994$ & $789 \pm 587$ & $682 \pm 366$ \\
\hline $\mathbf{L i}$ & $3.2 \pm 2.1$ & $3.8 \pm 3.2$ & $5.2 \pm 2.5$ & $3.4 \pm 1.0$ \\
\hline Mn & $707 \pm 351$ & $651 \pm 344$ & $234 \pm 161$ & $164 \pm 110$ \\
\hline Mo & $6.70 \pm 7.05$ & $8.80 \pm 5.70$ & $2.37 \pm 2.53$ & $8.65 \pm 6.41$ \\
\hline $\mathrm{Ni}$ & $64 \pm 29$ & $130 \pm 72$ & $83 \pm 81$ & $59 \pm 27$ \\
\hline $\mathbf{P b}$ & $5.84 \pm 2.44$ & $20.2 \pm 19.2$ & $24.2 \pm 26.6$ & $23.3 \pm 13.0$ \\
\hline
\end{tabular}




\begin{tabular}{|c|c|c|c|c|}
\hline Substance & $\begin{array}{c}\text { Scheibbs district } \\
\text { (Lower Austria) }\end{array}$ & $\begin{array}{c}\text { West of Vienna - } \\
\text { Vienna Woods }\end{array}$ & $\begin{array}{c}\text { Univ. of Nat. Res. Life } \\
\text { Sci. }\end{array}$ & Univ. Biocenter \\
\hline$[\mathbf{m g} / \mathbf{k g}]$ & $\boldsymbol{N = 1 6}$ & $\boldsymbol{N = 1 1}$ & $\boldsymbol{N}=\mathbf{7}$ & $\boldsymbol{N}=\mathbf{5}$ \\
\hline $\mathbf{S r}$ & $44 \pm 32$ & $60 \pm 23$ & $48 \pm 22$ & $45 \pm 9$ \\
\hline $\mathbf{V}$ & $<2$ & $<3$ & $<3-6$ & $<2$ \\
\hline $\mathbf{Z n}$ & $700 \pm 251$ & $654 \pm 480$ & $328 \pm 140$ & $626 \pm 447$ \\
\hline
\end{tabular}

* incomplete recovery of methionine; $N$ - number of samples

This can be explained by the collection strategy of the bees, which moved to a park close to the riverside (Donaukanal) nearby and did not cover their surrounding homogeneously. Bees flying to the highway or railway will never come back and others go to the site where something has been found. Similarly, bee hives put close to a highway did hardly contain contaminated honey [1]. High contribution of „less mineralized“ floral honey counteracts effects of the city, but even among ash-based data, the honeys from the rural area contained more $\mathrm{Cd}, \mathrm{Cu}$ and $\mathrm{Mn}$.

The city of Linz is a nucleus of steel and chemical industry in Austria, and had been a pollution hotspot from heavy industries in the past. Tables 7 and 8 contain honey data arranged within an approximate profile starting from rural areas north of the city, moving to northern suburbs, to a central area, and finally to southern suburbs (Molasse area). Whereas in the northern part, acid soils upon igneous rocks prevail, the city and its southern suburbs are situated in a Molasse zone of tertiary and quaternary origin.

Table 7

Honey samples around Linz/Upper Austria, per sample weight

\begin{tabular}{|c|c|c|c|c|}
\hline Element & $\begin{array}{l}\text { Igneous rock area; } \\
\text { woods close }\end{array}$ & $\begin{array}{c}\text { Igneous rock area; } \\
\text { gardens }\end{array}$ & $\begin{array}{l}\text { Close to the city; } \\
\text { gardens }\end{array}$ & Molasse area; woods close \\
\hline$[\mathrm{mg} / \mathrm{kg}]$ & $N=8$ & $N=10$ & $N=6$ & $N=4$ \\
\hline Al & $0.503 \pm 0.305$ & $0.596 \pm 0.355$ & $0.409 \pm 0.141$ & $0.517 \pm 0.239$ \\
\hline $\mathbf{B}$ & $7.61 \pm 2.01$ & $6.80 \pm 2.81$ & $9.06 \pm 2.81$ & $9.74 \pm 3.96$ \\
\hline Ba & $0.044 \pm 0.154$ & $0.084 \pm 0.118$ & $0.089 \pm 0.089$ & - \\
\hline $\mathbf{C a}$ & $63.6 \pm 17.3$ & $65.1 \pm 18.5$ & $66.0 \pm 13.7$ & $48.89 \pm 6.52$ \\
\hline Cd & $0.0011 \pm 0.0007$ & $0.0011 \pm 0.0006$ & $0.0017 \pm 0.0013$ & $0.0004 \pm 0.0003$ \\
\hline Co & $0.018 \pm 0.009$ & $0.016 \pm 0.009$ & $0.012 \pm 0.007$ & $<0.005$ \\
\hline $\mathrm{Cr}$ & $0.0059 \pm 0.0035$ & $0.0070 \pm 0.0032$ & $0.0049 \pm 0.0028$ & $0.0057 \pm 0.0028$ \\
\hline $\mathbf{C u}$ & $0.352 \pm 0.081$ & $0.424 \pm 0.136$ & $0.323 \pm 0.059$ & $0.140 \pm 0.036$ \\
\hline $\mathbf{F e}$ & $1.23 \pm 0.82$ & $1.07 \pm 0.41$ & $1.25 \pm 0.40$ & $0.72 \pm 0.10$ \\
\hline $\mathbf{K}$ & $1650 \pm 623$ & $1614 \pm 417$ & $1278 \pm 348$ & $516 \pm 253$ \\
\hline $\mathbf{L i}$ & $0.0035 \pm 0.0022$ & $0.0042 \pm 0.0022$ & $0.0042 \pm 0.0036$ & $0.0097 \pm 0.0098$ \\
\hline Mg & $25.3 \pm 11.5$ & $23.98 \pm 7.56$ & $22.11 \pm 4.21$ & $15.16 \pm 1.19$ \\
\hline Mn & $1.116 \pm 0.908$ & $1.343 \pm 0.994$ & $0.646 \pm 0.551$ & $0.261 \pm 0.096$ \\
\hline Mo & $0.0140 \pm 0.0140$ & $0.0124 \pm 0.0057$ & $0.0091 \pm 0.0034$ & $0.0052 \pm 0.0015$ \\
\hline $\mathbf{N a}$ & $10.15 \pm 3.03$ & $12.09 \pm 5.14$ & $10.56 \pm 4.91$ & $8.36 \pm 4.28$ \\
\hline $\mathbf{N i}$ & $0.125 \pm 0.032$ & $0.113 \pm 0.030$ & $0.121 \pm 0.047$ & $0.064 \pm 0.027$ \\
\hline $\mathbf{P}$ & $81.9 \pm 37.2$ & $66.8 \pm 22.1$ & $78.5 \pm 21.7$ & $48.9 \pm 9.1$ \\
\hline $\mathbf{P b}$ & $0.043 \pm 0.018$ & $0.036 \pm 0.021$ & $0.044 \pm 0.028$ & $0.044 \pm 0.031$ \\
\hline $\mathbf{S}^{*}$ & $16.64 \pm 4.91$ & $18.17 \pm 5.14$ & $19.87 \pm 4.41$ & $13.36 \pm 2.45$ \\
\hline $\mathbf{S r}$ & $0.096 \pm 0.036$ & $0.099 \pm 0.040$ & $0.068 \pm 0.019$ & $0.045 \pm 0.025$ \\
\hline $\mathbf{V}$ & $<0.007$ & $<0.007-0.009$ & $<0.007$ & $<0.007$ \\
\hline $\mathbf{Z n}$ & $1.185 \pm 0.348$ & $1.248 \pm 0.258$ & $0.887 \pm 0.281$ & $0.522 \pm 0.334$ \\
\hline
\end{tabular}

\footnotetext{
${ }^{*}$ incomplete recovery of methionine; $N$ - number of samples
} 
Among the main constituents, decrease of $\mathrm{K}$ and $\mathrm{P}$ together with increase in $\mathrm{B}$ indicate an increase of floral components from north to south. The levels of contaminant elements were at the same levels in the city area and outside. Among the corresponding ash-based data only, higher $\mathrm{Cd}$ appeared for the city sites. Among ash-based data, $\mathrm{Ca}, \mathrm{Mg}, \mathrm{Na}, \mathrm{Al}, \mathrm{B}$ and $\mathrm{S}$ were enriched in the Molasse zone, whereas data obtained from the original samples suggest the opposite. This might reflect differences in geology, but also the effect of some woods within the action range of the bees, resulting in higher total ash and lower $\% \mathrm{~K}$ in ash contents. Possibly, the proximity of highway A1 to the sites in the Molasse zone is reflected by higher $\mathrm{Pb}$ and $\mathrm{Cr}$ just in the ash-based data, too.

Table 8

Honey samples around Linz/Upper Austria, main element composition and trace elements per ash weight

\begin{tabular}{|c|c|c|c|c|}
\hline Substance & $\begin{array}{c}\text { Igneous rock area; } \\
\text { woods close }\end{array}$ & $\begin{array}{c}\text { Igneous rock area; } \\
\text { gardens }\end{array}$ & $\begin{array}{l}\text { Close to the city; } \\
\text { gardens }\end{array}$ & $\begin{array}{c}\text { Molasse area; } \\
\text { woods close }\end{array}$ \\
\hline$[\%]$ & $N=8$ & $N=10$ & $N=6$ & $N=4$ \\
\hline $\mathrm{K}_{2} \mathrm{O}$ & $82.86 \pm 1.99$ & $83.37 \pm 2.56$ & $78.85 \pm 1.86$ & $66.50 \pm 8.39$ \\
\hline $\mathbf{P}_{2} \mathbf{O}_{5}$ & $7.73 \pm 1.19$ & $6.81 \pm 1.15$ & $9.20 \pm 1.17$ & $12.90 \pm 2.07$ \\
\hline $\mathrm{CaO}$ & $3.86 \pm 0.53$ & $3.93 \pm 0.68$ & $4.82 \pm 0.62$ & $8.09 \pm 2.30$ \\
\hline MgO & $1.74 \pm 0.43$ & $1.69 \pm 0.19$ & $1.92 \pm 0.26$ & $3.02 \pm 0.95$ \\
\hline $\mathrm{SO}_{3}{ }^{*}$ & $1.81 \pm 0.34$ & $1.97 \pm 0.35$ & $2.61 \pm 0.46$ & $3.88 \pm 0.81$ \\
\hline $\mathrm{Na}_{2} \mathrm{O}$ & $0.63 \pm 0.30$ & $0.72 \pm 0.31$ & $0.74 \pm 0.35$ & $1.21 \pm 0.27$ \\
\hline $\mathrm{B}_{2} \mathrm{O}_{3}$ & $1.23 \pm 0.74$ & $1.03 \pm 0.65$ & $1.66 \pm 0.97$ & $4.12 \pm 2.71$ \\
\hline \multicolumn{5}{|l|}{$[\mathrm{mg} / \mathrm{kg}]$} \\
\hline Al & $212 \pm 104$ & $254 \pm 122$ & $212 \pm 78$ & $589 \pm 251$ \\
\hline $\mathbf{B a}$ & $9 \pm 58$ & $38 \pm 50$ & $38 \pm 44$ & \\
\hline Cd & $0.49 \pm 0.26$ & $0.46 \pm 0.21$ & $0.92 \pm 0.74$ & $0.45 \pm 0.32$ \\
\hline Co & $7.5 \pm 2.4$ & $6.5 \pm 2.8$ & $6.2 \pm 3.0$ & $<6$ \\
\hline $\mathrm{Cr}$ & $2.57 \pm 1.45$ & $3.15 \pm 1.71$ & $2.53 \pm 1.60$ & $7.63 \pm 5.58$ \\
\hline $\mathrm{Cu}$ & $158 \pm 45$ & $188 \pm 59$ & $171 \pm 35$ & $161 \pm 37$ \\
\hline $\mathbf{F e}$ & $476 \pm 152$ & $485 \pm 188$ & $648 \pm 175$ & $876 \pm 364$ \\
\hline $\mathbf{L i}$ & $1.4 \pm 0.5$ & $1.8 \pm 1.0$ & $2.2 \pm 2.0$ & $9.5 \pm 5.7$ \\
\hline Mn & $495 \pm 365$ & $568 \pm 382$ & $353 \pm 311$ & $333 \pm 199$ \\
\hline Mo & $5.01 \pm 3.44$ & $5.33 \pm 1.84$ & $4.62 \pm 0.62$ & $5.86 \pm 1.03$ \\
\hline $\mathrm{Ni}$ & $56 \pm 16$ & $49 \pm 12$ & $64 \pm 25$ & $70 \pm 7$ \\
\hline $\mathbf{P b}$ & $19.9 \pm 11.9$ & $17.5 \pm 14.6$ & $23.3 \pm 16.1$ & $45.3 \pm 22.6$ \\
\hline $\mathbf{S r}$ & $41 \pm 11$ & $42 \pm 12$ & $35 \pm 3$ & $49 \pm 20$ \\
\hline $\mathbf{V}$ & $<2$ & $<3-5$ & $<3$ & $<5$ \\
\hline $\mathbf{Z n}$ & $565 \pm 286$ & $565 \pm 191$ & $464 \pm 163$ & $542 \pm 147$ \\
\hline
\end{tabular}

${ }^{*}$ incomplete recovery of methionine

\section{Conclusions}

Because honey samples may cover a rather large area, their use as indicator substances to detect environmental pollution seems promising. However, data from monofloral honeys show that effects of plant origin and soil composition prevent tracing the exact composition of a non-contaminated baseline sample. Also, contrary to soils and sediments, honey samples from a pre-industrial era contained trace elements at higher levels than current.

Determination of the inorganic matrix permits the calculation of the presumable ash contents and composition, which is largely a K-phosphate borate. Interpretation of the inorganic matrix of honey samples in terms of environmental contamination is biased by effects of green plant origin, in particular differences in ash contents of floral and 
honeydew honey. Because dilutions by the sugar matrix are eliminated, ash-based data reflect inputs from dust and pollen in a more reliable way. Ash-based data show $\mathrm{Cd}, \mathrm{Pb}$ and $\mathrm{Co}$ at about the same levels than expectable in dust, whereas $\mathrm{Cu}$, Mo and $\mathrm{Zn}$ get enriched by physiological reasons and thus should not be taken as proper indicators for environmental contaminations.

Due to the sampling strategy of the honeybees to collect at specific spots instead of homogenous sampling at the entire area, however, differences between urban, suburban and agricultural areas in Vienna and Linz were small and within experimental errors.

\section{References}

[1] Leita L, Muhlbachova G, Cesco S, Barbattini R, Mondini C. Investigation of the use of honey bees and honey bee products to assess heavy metals contamination. Environ Monit Assessm. 1996;43(1):1-9. DOI: 10.1007/BF00399566.

[2] Sager M, Pechhacker H, Pechhacker M. Trace elements in honey. Chem Inż Ekol - Ecol. Chem Eng. 2002;9(4):461-472.

[3] Sager M, Maleviti E. Elemental composition of honeys from Greece - possible use as environmental indicators. J Nutrition Food Sci. 2014;S8:002. DOI: 10.4172/2155-9600.S8-002.

[4] Pechhacker M, Sager M, Pechhacker H. About the influence of soil on the trace element composition of honey. In: Szilágyi M, Szentmihályi K, editors. Trace Elements in the Food Chain Vol. 3. Deficiency or Excess in the Environment as a Risk to Health. Working Committee on Trace Elements of the Hungarian Academy of Sciences (HAS), Institute of Materials and Environmental Chemistry of the HAS, Budapest, Hungary. 2009; 61-65. ISBN 978-963-7067-19-8.

[5] Gautam I. Antibacterial activity and element spectrum of Nepali honey from different bee species (Hymenoptera: apidae). [PhD Thesis]. Vienna: University of Natural Resources and Life Sciences; 2004. http://lib.icimod.org/record/324/files/324.pdf.

[6] Schachner D. Möglichkeiten und Grenzen der Prüfung der Authentizität von Honig (Possibilities and limitations to check authenticities of honey). Institut für Lebensmittelsicherheit Linz; AGES Report 2013.

[7] Sager M, Pechhacker H, Burgstaller H. Vergleich der Spurenelementzusammensetzung historischer und rezenter Honige Tirols (Comparison between trace element compositions of historic and recent honeys from the Tyrol). Wien: ALVA Tagung; 2004.

[8] Jones KC. Honey as an indicator of heavy metal contamination. Water Air Soil Pollut. 1987;33:179-189. ISSN: 0049-6979.

[9] Dobrzanski Z, Roman A, Gorecka H, Kolacz R. Zawartość pierwiastków szkodliwych oraz makro- i mikroelementów w miodach pszczelich z rejonów skażeń przemysłowych. (Metals and micro and macroelements content of beehoney gained from the areas contained by industrial plants). Brom Chem Toksykol. 1994;27(2):157-160.

[10] Bulinski R, Wyszogrodzka-Koma L, Marsec Z. Badanie zawartości niektórych pierwiastków śladowych w produktach spożywczych krajowego pochodzenia. (Study of some trace elements content of home food products). Bromat Chem-Toksykol. 1995;28(2):151-154. bwmeta1.element.agro-article-3113fee2-dd6749d9-abed-ee49fbbaf7f9.

[11] Conti ME, Botre F. Honeybees and their products as potential bioindicators of heavy metals contamination. Environ Monit Assess. 2001;69(3):267-282. DOI: 10.1023/A:1010719107006.

[12] Fernandez-Torres R, Pérez-Bernal JL, Bello-López MÁ, Callejón-Mochón M, Jiménez-Sánchez JC, Guiraúm-Pérez A. Mineral content and botanical origin of Spanish honeys. Talanta. 2005;65:686-691. DOI: 10.1016/j.talanta.2004.07.030.

[13] Freitas MC, Pacheco AMG, Ferreira E. Nutrients and other elements in honey from Azores and mainland Portugal. J Radioanalyt Nuclear Chem. 2006;270(1):123-130.

[14] Fredes C, Montenegro G. Heavy metals and other trace elements contents in Chilean Honey. Ciencia e Investigacion Agraria. 2006;33(1):48-55. www.rcia.uc.cl/index.php/rcia/article/view/328/252.

[15] Rashed MN, Soltan ME. Major and trace elements in different types of Egyptian mono-floral and non-floral bee honeys. J Food Composit Analysis. 2004;17:725-735. DOI: 10.1016/j.jfca.2003.10.004.

[16] Tuzen M, Silici S, Mendil D, Soylak M. Trace element levels in honeys from different regions of Turkey. Food Chem. 2007;103:325-330. DOI: 10.1016/j.foodchem.2006.07.053.

[17] Molan PC. The antibacterial activity of honey. Bee World. 1992;5-28. DOI: 10.1080/0005772X.1992.11099109. 